\title{
MORPHOLOGICAL GHARACTERISTICS AND METHODS FOR BREAKING SEED DORMANCY IN ENTEROLOBIUM CONTORTISILIQUUM SPECIMENS FROM THE AMAZONIAN BIOME
}

\author{
de Sousa PS ${ }^{1}$, da Silva JA², Moura EG ${ }^{3}$, Nardis BO $^{4}$, da Silva RF ${ }^{5}$, Gil RL \& Andrade FR $^{1}$, * \\ ${ }^{1}$ Federal Institute of Education, Science and Technology of Mato Grosso, Juina-MT, 78.320-000, Brazil \\ ${ }^{2}$ Floriano Technical College, Federal University of Piaui, Floriano-PI, 64.808-605, Brazil \\ ${ }^{3}$ Federal Institute of Education, Science and Technology of Maranhão, São João dos Patos-MA, 65.665-000, Brazil \\ ${ }^{4}$ Federal University of Lavras, Lavras - MG, 37.200-000, Brazil \\ ${ }^{5}$ Federal University of Piaui, Bom Jesus-PI, 64.900-000, Brazil
}

*fabricio.andrade@jna.ifmt.edu.br

Submitted April 2020; accepted October 2020

\begin{abstract}
Characterisation and reproduction studies of Amazonian species are extremely important for the recovery and preservation of this biome. The objective of this study was to morphologically characterise the fruits and seeds of Enterolobium contortisiliquum, as well as to verify the influence of seed mass and methods for breaking dormancy. Two evaluation periods consisting of 100 fruits and 500 seeds were analysed for morphological parameters. An experimental design of a complete randomised $2 \times 3 \times 3$ factorial scheme was used to assess the effect of time in storage, mass and breaking dormancy. The important factors consisted of two periods (one and five months after seed collection), three classes of seed mass $(<0.877 \mathrm{~g}, 0.887-1.09 \mathrm{~g}$ and $>1.09 \mathrm{~g})$ and two methods for breaking dormancy (sulphuric acid and mechanical scarification + control group) were identified. The evaluated parameters were germination, germination speed index, stem diameter, average germination time, radicle length, seedling height and the fresh and dry weights of root, shoot and total biomass. Mechanical scarification and sulphuric acid immersion promoted breaking dormancy in seeds of E. contortisiliquum, while the medium and large seeds showed better initial development. Mechanical scarification is recommended for breaking the seed dormancy of this species.
\end{abstract}

Keywords: Forest conservation, germination, scarification, storage time, improved germination

\section{INTRODUCTION}

The Amazon biome encompassed approximately $30 \%$ of the world's remaining tropical forests (MMA 2010). Additionally, these biomes covered a vast territory of 4.2 million $\mathrm{km}^{2}$ which contained 53 ecosystems (Sayre et al. 2008). It provided more than 600 habitat types and to about 45,000 species of plants and vertebrates (MMA 2010). However, recurrent deforestations had endangered the species which inhabit this biome, thus heightened the need for emergency measures for conservation and restoration of degraded areas (Melo et al. 2011).

Several Amazonian plant species are known for their nutritional, medicinal, timber and ornamental values. Among these species, Enterolobium contortisiliquum, which is a fast growing pioneer tree species with low nutritional requirements and high resistance to water stress, is used to recover degraded areas and polyculture systems (Santos \& Santos 2010).

Enterolobium contortisiliquum seeds did not germinate homogeneously due to their dormancy period, which was one of the main obstacles for the use of this species in forestry projects (Alexandre et al. 2009). The impermeability of the seed coat seemed to be the cause of dormancy in Fabaceae seeds (Gama et al. 2011, Oliveira et al. 2012). Therefore, techniques for breaking seed dormancy were suggested, for example mechanical scarification (Oliveira et al. 2012), sulphuric acid immersion (Costa et al. 2010) and sandpaper scarification (Gama et al. 2011). Sandpaper scarification was performed on both sides of the seed, opposite to the micropyle 
(Cardoso et al. 2012) or opposite to the hilum (Coelho et al. 2010). However, the effectiveness of the method varied among the different species of this family.

In recent years, interest in the propagation of native forest species has increased (Benedito et al. 2008). However, morphometric information on the fruit and seed characteristics of E. contortisiliquum was still incipient, as was the case for many other species of the Amazon biome (Araujo et al. 2004). Morphological description is a powerful tool for detecting phenotypic variation within tree populations and can provide fundamental information for species differentiation (Cruz \& Carvalho 2003, Gusmão et al. 2006) and the formation of germplasm banks (Gonçalves et al. 2013). These banks serve as the basis for the conservation and exploration of the economic resources from these species, allowing the continuous and effective use of their fruits and seeds (Gusmão et al. 2006). Thus, the objective of this study was to morphologically characterise fruits and seeds, as well as to investigate the efficiency of different methods for breaking dormancy in E. contortisiliquum seeds over two evaluation periods.

\section{MATERIALS AND METHODS}

\section{Materials preparation}

The experiment was conducted between July and August 2015 and fruits of E. contortisiliquum (Figure 1) were collected from healthy trees, located in the urban and rural areas of Juína, Mato Grosso state, Brazil ( $11^{\circ} 26^{\prime} \mathrm{S}$ and $58^{\circ} 43^{\prime} \mathrm{W}$ at $320 \mathrm{~m}$ altitude) with no deformities in the stem. The fruits were placed in paper bags and taken to the Biology Laboratory of the Federal Institute of Education, Science and Technology of Mato Grosso to be manually processed and stored.

\section{Morphological analysis}

Morphological evaluations were performed using 100 fruits based on the suggestions of Czeder et al. (2012) and Gonçalves et al. (2013). The fruits were randomly selected from a bigger sample of 150 fruits, visually healthy, whole and without deformations as recommended by Gusmão et al. (2006) (Table 1).

Table 1 Width, length, diameter, fresh fruit mass, number of seeds, weight of seeds, pulp mass, moisture and volume index in fruits and seeds of Enterolobium contortisiliquum

\begin{tabular}{lrrrrrrrr}
\hline \multicolumn{1}{c}{ Parameter } & Min. & Mean & Median & Max. & Asymmetry & Kurtosis & SD & CV $(\%)$ \\
\hline Width (mm) & 71.68 & $92.26 \pm 1.90$ & 91.71 & 115.25 & 0.513 & -0.245 & 9.705 & 10.51 \\
Length (mm) & 31.16 & $46.80 \pm 2.14$ & 46.12 & 62.34 & 0.250 & 0.690 & 5.449 & 11.64 \\
Diameter (mm) & 11.70 & $17.78 \pm 0.35$ & 17.72 & 23.93 & -0.084 & 1.811 & 1.781 & 10.02 \\
Fresh fruit mass (g) & 24.43 & $48.94 \pm 2.30$ & 49.40 & 97.47 & 0.738 & 1.745 & 11.701 & 23.90 \\
NS (unit) & 10.00 & $17.14 \pm 0.70$ & 17.00 & 28.00 & 0.730 & 0.568 & 3.598 & 21.00 \\
NVS (unit) & 5.00 & $15.51 \pm 0.75$ & 15.00 & 26.00 & 0.218 & 0.388 & 3.791 & 24.44 \\
MVS (g) & 3.40 & $14.05 \pm 0.75$ & 14.34 & 21.49 & -0.437 & -0.499 & 3.809 & 27.10 \\
DPM (g) & 15.22 & $31.57 \pm 1.67$ & 31.09 & 70.40 & 1.130 & 3.113 & 8.554 & 27.09 \\
PM (\%) & 1.41 & $7.13 \pm 0.31$ & 6.92 & 14.26 & 1.834 & 8.308 & 1.587 & 22.23 \\
\hline & & & Seeds & & & \\
\hline Length (cm) & 13.07 & $17.77 \pm 0.13$ & 17.72 & 22.38 & 0.298 & 0.283 & 1.586 & 8.92 \\
Width (cm) & 6.82 & $10.36 \pm 0.09$ & 10.56 & 12.56 & -0.633 & 0.096 & 1.021 & 9.85 \\
Diameter (mm) & 4.68 & $7.12 \pm 0.07$ & 7.34 & 8.7 & -0.542 & -0.653 & 0.780 & 10.95 \\
SVI (mL) & 0.62 & $1.31 \pm 0.02$ & 1.34 & 1.942 & -0.251 & -0.623 & 0.241 & 18.32 \\
Seed mass (g) & 0.43 & $0.93 \pm 0.01$ & 0.94 & 1.333 & -0.241 & -0.535 & 0.175 & 18.67 \\
SM (\%) & 0.19 & $3.72 \pm 0.13$ & 3.86 & 13.16 & 0.967 & 6.108 & 1.476 & 39.58 \\
\hline
\end{tabular}

$\mathrm{SD}=$ standard deviation, $\mathrm{CV}=$ coefficient of variation; $\mathrm{NS}=$ number of seeds, NVS = number of viable seeds, MVS = mass of viable seeds per fruit, DPM = dry pulp mass, PM = pulp moisture, $\mathrm{SVI}=$ seed volume index, $\mathrm{SM}=$ seed moisture 


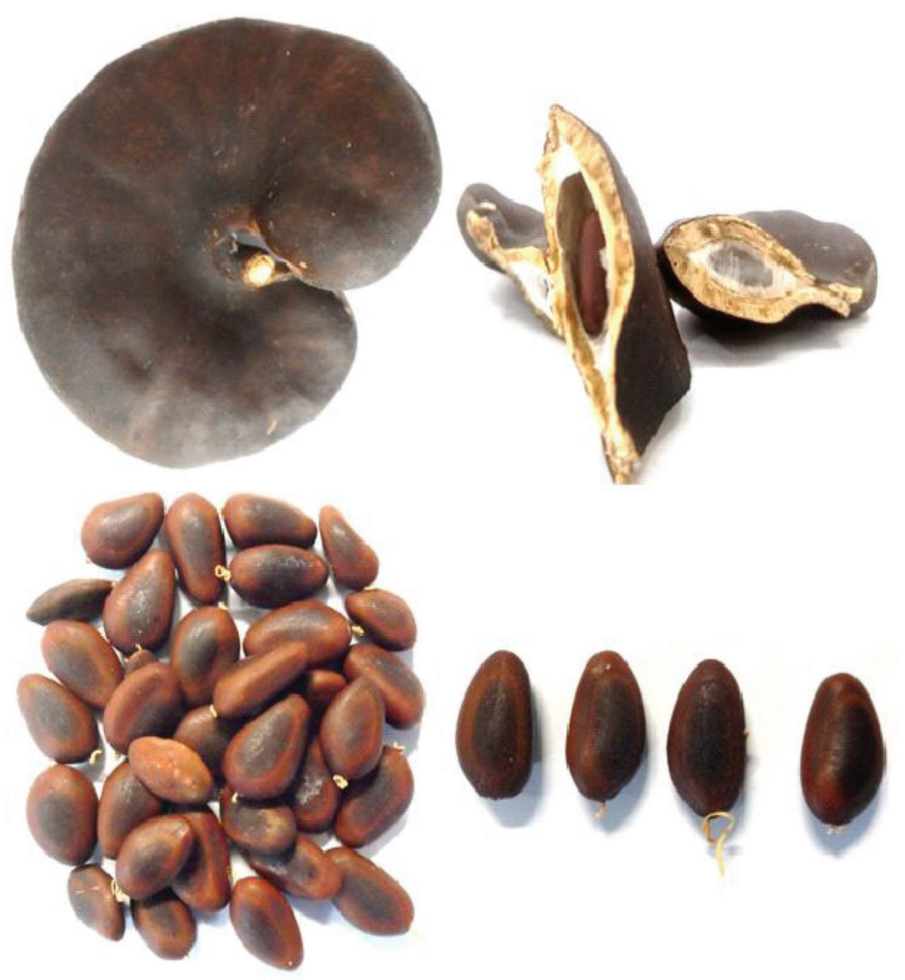

Figure 1 Fruits and seeds of Enterolobium contortisiliquum collected in the municipality of Juína, Mato Grosso, Brazil

After the selection, fruit width, longitudinal fruit length, equatorial diameter of the fruit, fresh mass of the fruit, number of seeds per fruit, number of viable seeds per fruit, mass of viable seeds per fruit and dry pulp mass were recorded. Consecutively, five seeds from each fruit were randomly chosen to determine the seed width, longitudinal seed length, equatorial diameter of the seed and fresh seed mass.

Fruit and seed dimensions (length, width and thickness) were measured with a pair of callipers. Fresh mass measurements were obtained using an analytical balance. The fruit pulp and seeds were then individually separated into paper bags and dried in a forced circulation oven for 24 hours at $105^{\circ} \mathrm{C}$. They were subsequently weighed on a precision scale and seed moisture and pulp were determined.

The seed volume index was calculated by multiplying seed length, width and thickness. The mass of each seed was determined and then added to the remaining seeds to determine the weight of 1000 seeds, following the criteria established by the Rules for Seed Analysis (MAPA 2009).

\section{Seed mass and methods for breaking dormancy}

The experimental design was a complete randomised $2 \times 3 \times 3$ factorial design, with the factors assessed in two periods (one and five months after seed collection), three seed mass classes $(<0.887 \mathrm{~g}$ (small), 0.887-1.090 $\mathrm{g}$ (medium) and $>1.090 \mathrm{~g}$ (large) ) and two methods for breaking seed dormancy (sulphuric acid immersion for $15 \mathrm{~min}$ and mechanical scarification of the region opposite the hilum) + control (without treatment)) with a total of 18 treatments with four iterations of 25 seeds.

After the selection process, the seeds were immersed in a solution containing $5 \%$ sodium hypochlorite for $5 \mathrm{~min}$ and washed under running water to inhibit fungal infections (MAPA 2009). For the treatment with sulphuric acid (98\% pure analytic), the seeds were submerged in this solution for $15 \mathrm{~min}$. After immersion, the seeds were placed in a steel sieve, washed under running water for $10 \mathrm{~min}$ and dried on paper sheets. Mechanical scarification was performed with the aid of an electric grinder, sanding the region opposite the hilum. 
The test was performed on two sheets of paper, and then covered with an additional sheet, which was previously moistened with distilled water at 2.5 times the weight of the paper. After sowing, the sheets were arranged in rolls and placed in transparent plastic packaging, in order to maintain the moisture. The rolled sheets were identified and kept in a BOD Incubator (Bio-Oxygen Demand), with a light intensity of $15 \mathrm{~W}$, temperature at $30{ }^{\circ} \mathrm{C}$ and a photoperiod of 12 hours (Lessa et al. 2014). Seeds with root protrusion of at least $2 \mathrm{~mm}$ were considered germinated (Oliveira et al. 2006). Percentage of germinated seedlings in the study and the germination speed index were evaluated based on Maguire (1962).

At the end of the study, average germination time was obtained by calculating the number of emerged seedlings on daily evaluations (Edwards 1934). Finally, the percentage of remaining living or dead seeds was determined by longitudinal dissection as recommended by Rules for Seed Analysis (MAPA 2009). Seedling height was determined from the measurement from the base of the seedling stem to the apex of the apical meristem and the radicle length from the measurement from the base of the stem to the root end of the seedling. Both measurements were carried out using a graduated ruler. The stem diameter was determined using a pair of digital callipers.

Fresh root and shoot biomass were obtained using an analytical balance from a sample of 10 seedlings per plot. The samples were oven dried at an average temperature of $65^{\circ} \mathrm{C}$ until constant mass was reached.

\section{Statistical analysis}

The morphological characteristics of fruits and seeds were analysed using descriptive statistics. In the study to determine the breaking of dormancy in different seed sizes and time periods, analysis of variance was performed using the F-test $(\mathrm{p} \leq 0.05)$ and means were compared using the Scott-Knott test $(\mathrm{p} \leq 0.05)$. The statistical analysis was carried out using the statistical software $R$ 3.2.3.

\section{RESULTS AND DISCUSSION}

In the evaluation of the morphological characteristics of the fruits and seeds, the recorded data showed their asymmetry and kurtosis values close to zero, which indicated an approximation of the normal distribution; with the exception of dry pulp mass, pulp moisture and seed moisture. The coefficients of variation for the measured parameters ranged from $8.92-39.58 \%$, similar to the values obtained by Gonçalves et al. (2013) and Zuffo et al. (2014) for mangaba (Hancornia speciosa) and baru (Dipteryx alata), respectively in the eastern region of Mato Grosso state in, Brazil. Thus, the high variability might be attributed to the phenotypic heterogeneity of these individuals, which was reported by Silva et al. (2001) was due to uncontrolled environmental factors, such as anthropisation, edaphic factors, climatic factors, plant age and genetic differences.

Frequency distribution values related to fruits and seeds of $E$. contortisiliquum were shown as follows; fruit width $(77.90-96.57 \mathrm{~mm}, 70 \%$ of the total), longitudinal fruit length (40.06-53.43 $\mathrm{mm}, 81 \%$ ), equatorial diameter of the fruit (15.19-20.43 mm, 90\%), fresh mass of fruit (34.86-66.16 g, 88\%), number of seeds per fruit (12.57-20.28 units, 77\%), number viable seeds per fruit (11-20 units, $80 \%$ ), mass of viable seeds per fruit $(11.15-18.90 \mathrm{~g}, 69 \%)$, dry pulp mass (23.10-38.86\%, 81\%), pulp mass $(5.08-8.75 \%$, $92 \%)$, seed width $(9.28-11.74 \mathrm{~mm}, 77 \%)$, longitudinal seed length (15.73-19.72 mm, $78 \%)$, equatorial diameter of the seed $(6.40-8.12$ $\mathrm{mm}, 72 \%)$, seed volume index $(1.00-1.56 \mathrm{~mL}$, $75 \%)$, fresh seed mass $(0.693-1.077 \mathrm{~g}, 68 \%)$, and seed moisture $(0.190-5.750 \%, 98 \%)$ (Figure 2$)$.

The fruit and seed dimensions found in this study differed from those obtained by Barretto and Ferreira (2011) in the morphological characterisation of this species in the state of Sergipe, Brazil, where E. contortisiliquum fruits were found to be approximately 79.0, 42.0 and $16.0 \mathrm{~mm}$ in width, length and diameter respectively containing 12 to 15 seeds per fruit. According to Barretto and Ferreira (2011), the seeds were flat and oblong with average length of $13.50 \pm 1.27 \mathrm{~mm}$, width of $9.5 \pm 0.93 \mathrm{~mm}$ and thickness of $6.60 \pm 0.76 \mathrm{~mm}$. The slightly higher values observed in the present study for the characteristics of number of seeds per fruit, seed width and longitudinal seed length might link to the relatively higher rainfall of the Amazon region than in north-eastern climates, which allowed better development of the fruits and seeds of this species. As shown in this 


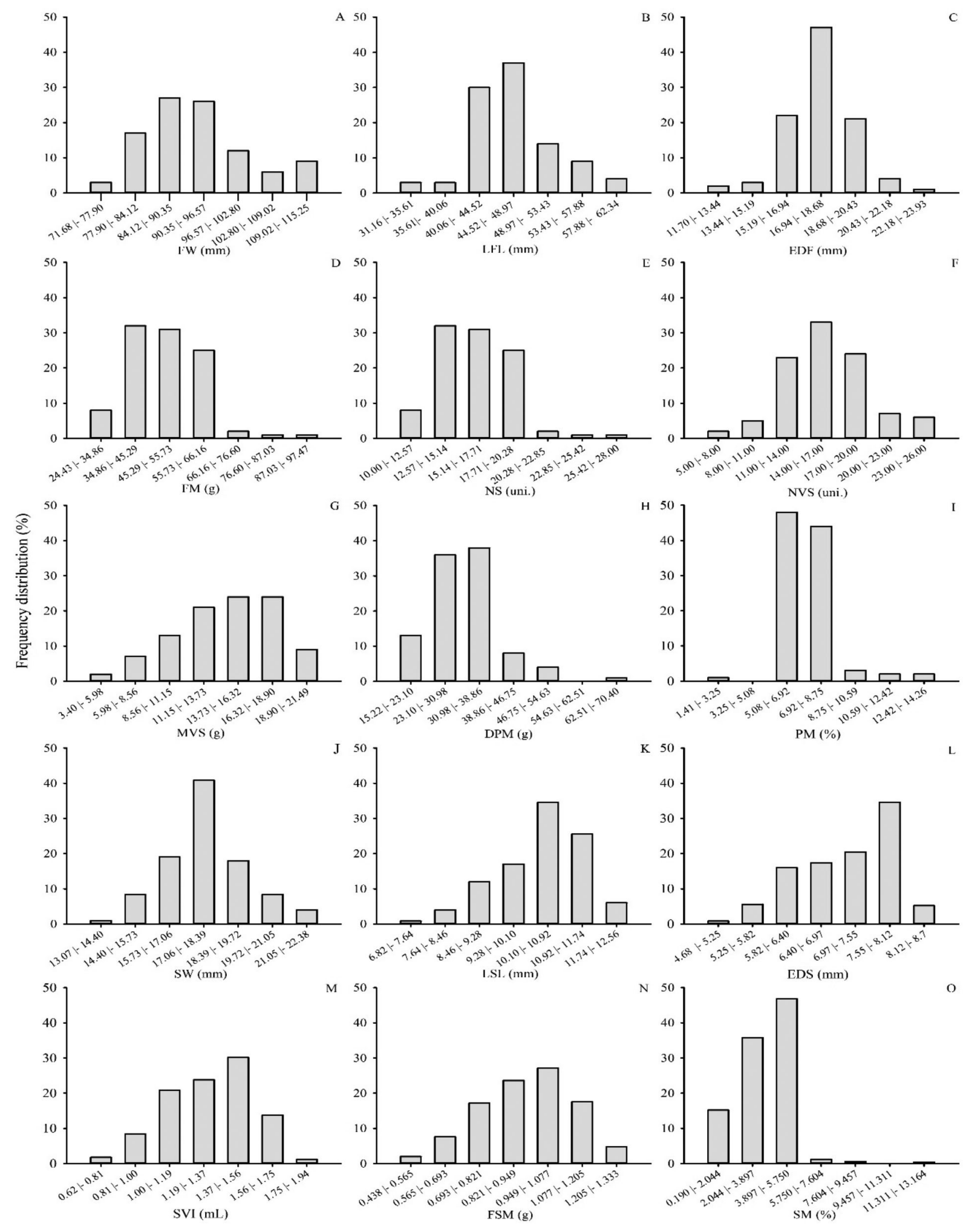

$\mathrm{FW}=$ fruit width, $\mathrm{LFL}=$ longitudinal fruit length, $\mathrm{EDF}=$ equatorial diameter of fruit, $\mathrm{FM}=$ fresh mass of fruit, NS = number of seeds per fruit, NVS = number viable seeds per fruit, MVS = mass of viable seeds per fruit, $\mathrm{DPM}=$ dry pulp mass, $\mathrm{PM}=$ pulp mass, $\mathrm{SW}=$ seed width), $\mathrm{LSL}=$ longitudinal seed length, $\mathrm{EDS}=$ equatorial diameter of the seed, SVI = seed volume index, FSM = fresh seed mass, $\mathrm{SM}=$ seed moisture

Figure 2 Frequency distribution of the morphological properties of fruits and seeds of E. contortisiliquum 
study, tropical tree species expressed significant variability in their fruits and seeds (Cruz \& Carvalho 2003, Zuffo et al. 2014). The variability may influence the adaptive value of the parent trees, their regenerative capacity (Moraes \& Alves 2002) and mainly found in species with typical seeds (Wielewick et al. 2006).

Thus, fruit and seed dimensions as well as mass provide vital information for reforestation programmes, as these criteria contribute to greater success in germination and vigour of different species (Upadhaya et al. 2007, Socolowski et al. 2013). According to Santos Neto et al. (2009), the greater accumulation of reserves in fruit and seed may cause better formation of the embryo. It is also noteworthy that these seed characteristics influence the establishment and dispersal of species (Braga et al. 2007).

When evaluating the influence of seed mass, time period and breaking dormancy method on germination and initial development of $E$. contortisiliquum, significant effects were observed for the analysed variables. For germination, germination speed index, stem diameter, radicle length and seedling height showed significant effects between all studied factors. These results were consistent, because E. contortisiliquum demonstrated a dormancy process caused by the thick seed coat and by having embryonic seed dormancy (Scalon et al. 2005).

These results corroborated the work of Socolowski et al. (2013) on the methods for breaking seed dormancy and/or with seed mass to verify their effects on germination and initial seedling development. Similarly, Alexandre et al. (2009) found positive effects on physical and chemical treatments for breaking seed dormancy for E. contortisiliquum.

The best seed germination rate was obtained in seeds immersed in sulphuric acid and mechanical scarification in the region opposite to the hilum, independent of seed mass and storage time (Figure 3). When a treatment to break seed dormancy was employed, the average germination rate was $94 \%$. These results were higher than those found by Scalon et al. (2005) when immersion in sulphuric acid for 10 min was used and Alexandre et al. (2009) when mechanical scarification was applied, which obtained 83 and $80 \%$ germination rates respectively. However, Lozano et al. (2016) used the mechanical scarification and chemical scarification with sulphuric acid method for 30 to 50 min to obtain $100 \%$ germination rates of seeds of the Enterolobium contortisiliquum collected in Choromoro in Argentina. Among the factors that might have contributed to the higher germination rate in this study were the longer immersion time in sulphuric acid as well as environmental factors. They influenced seed formation, such as the hardness of the seed coat, resulting in longer or shorter dormancy period.

Germination was influenced by seed mass in the second period of the study when compared to the control group. Regardless of storage time, seeds with higher mass had up to $34 \%$ higher germination rates. However, smaller seeds submitted to dormancy breaking treatments had significantly higher germination rates than large seeds not submitted to these treatments, even though the latter exhibited the highest no-treatment germination rates in this period (Figure 3).

In a study on Tecoma stans, the seed mass influenced germination and seeds with a larger mass resulted in a greater number of seedlings (Socolowski et al. 2013). Santos Neto et al. (2009) and Khan (2004) reported that, due to the amount of accumulated reserves and embryo formation, seed size and mass were considered indicators of physiological quality, since lighter seeds usually showed poorer performance in both germination and initial plant growth. The highest seed germination rate in the absence of treatment for breaking dormancy in the second period was related to the increasing integument permeability with longer storage time, as observed in other species of the Leguminosae family (Santarém \& Aquila 1995).

Germination speed index was influenced by dormancy breaking methods and the use of sulphuric acid promoted higher rates of germination in the first period regardless of mass (Figure 4). In the second period, dormancy breaking methods did not differ from each other (Figure 4). Seed mass only exerted influence on the control in the second period, where seeds with higher mass presented better germination speed index when compared with seeds of lower mass. When comparing storage time, results showed that seeds stored longer have higher germination speed index, except for medium and large seeds treated with sulphuric acid and small and medium seeds when submitted to no 


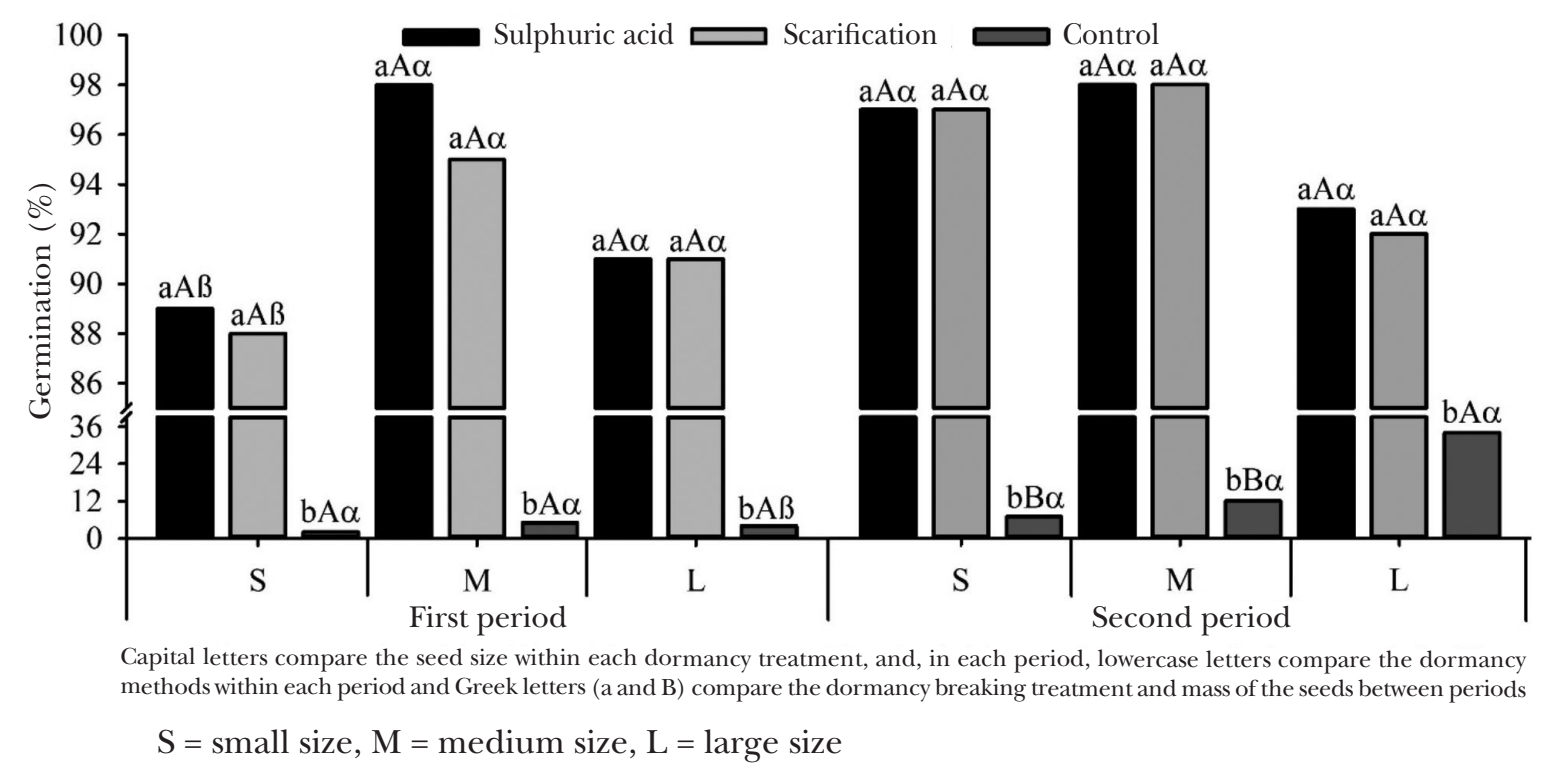

Figure 3 Effect of periods, seed size and methods for overcoming dormancy on E. contortisiliquum seed germination

treatment (Figure 4). These results partially corroborated finding obtained by Alexandre et al. (2009) who verified the highest germination speed index for mechanically scarified plants. In addition, Zonta et al. (2011) found that the germination speed index of physic nut (Jatropha curcas) seeds was influenced by their mass, where the ones with higher mass germinated faster.

The best germination speed index in scarified seeds was the result of opening or sectioning the integument allowing for tissue hydration, which enabled metabolic reactions necessary for germination (Andrade et al. 2010). Thus, the rapid germination of some seedlings provided a greater advantage over the others, as they were exposed to favourable environmental conditions, such as moisture, nutrients and light as they competed under the shade with individuals of the same species germinating at a later time.

In general, the E. contortisiliquum seedlings germinated in the second period had stems with larger diameters, except for the medium sized seeds not subjected to dormancy breaking methods. Mechanical scarification treatment resulted in seedlings with the longest stem diameter independent of seed mass, with the exception of medium seeds in the first period, where the control had the longest stem diameter. Overall, small seeds showed the smallest values for stem diameter, except when subjected to mechanical scarification (Figure 5). In a study on the size of pitanga (Eugenia uniflora L.) seeds, Klein et al (2007) put forward similar results to those found in this study, where smaller seeds produced seedlings with smaller diameters. Thus, the results obtained were related to White and González's (1990) hypothesis that a larger seed mass enables greater improvement in plant development.

Methods for breaking seed dormancy promoted the largest increase in radicle length in small and large seeds in the first period and medium seeds in the second period. Additionally, when comparing seed sizes, it was observed that small seeds in the first period and small and medium seeds in the second period showed higher radicle growth. When assessing by time period, higher radicle length occurred in small seeds which received both treatments to break seed dormancy and large seeds immersed in sulphuric acid in the first period. The results showed that in smaller seeds with a shorter storage time but with the treatments for breaking dormancy had resulted in larger radicles (Figure 6). Silva et al. (2012), studied the dormancy breaking methods on the same species, however, found no effects of dormancy breaking methods on radicle length. The data obtained in this study resembled the findings of Dresch et al. (2013) which reported less development of the root system of Campomanesia adamantium (Myrtaceae) seedlings from fruits with greater mass. 


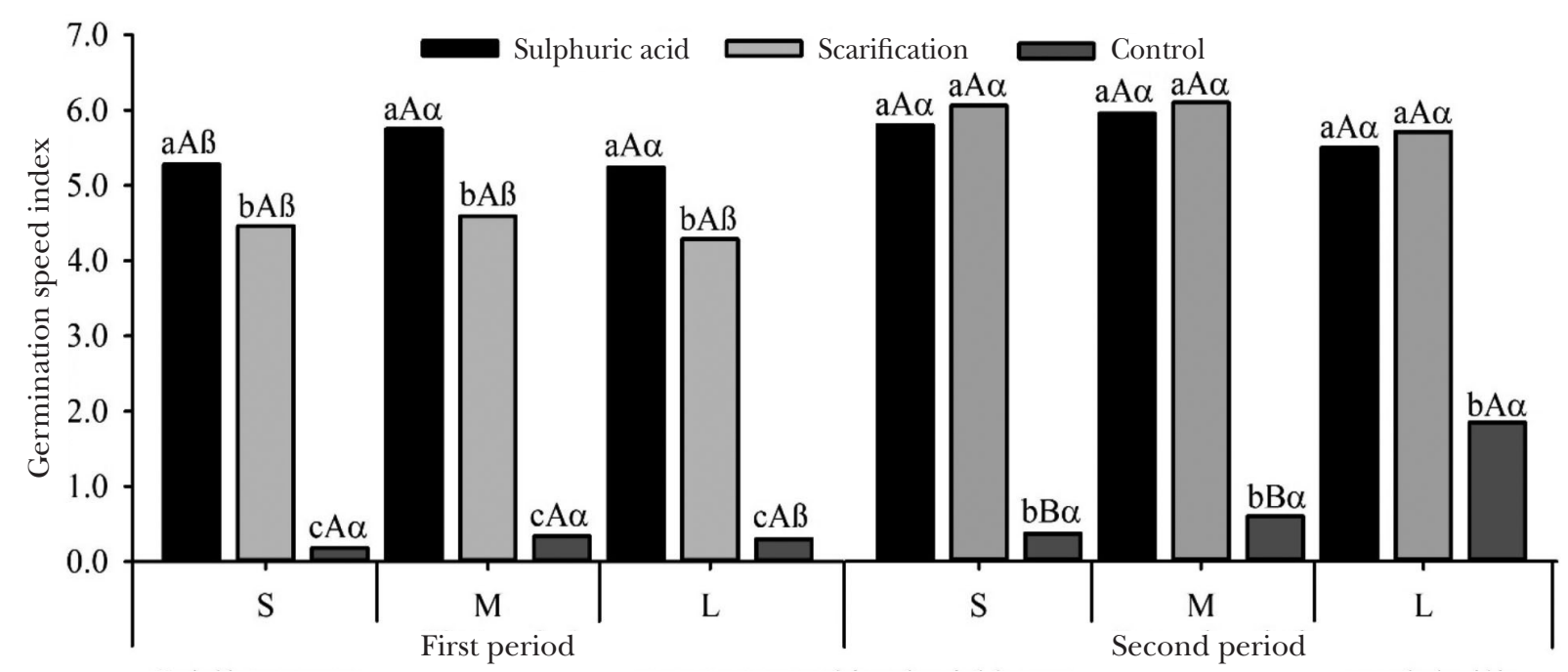

Capital letters compare the seed size within each dormancy treatment, and, in each period, lowercase letters compare the dormancy methods within each period and Greek letters ( $\mathrm{a}$ and $\mathrm{B}$ ) compare the dormancy breaking treatment and mass of the seeds between periods

$\mathrm{S}=$ small size, $\mathrm{M}=$ medium size, $\mathrm{L}=$ large size

Figure 4 Effect of periods, seed size and methods for breaking dormancy on E. contortisiliquum in seed germination speed index

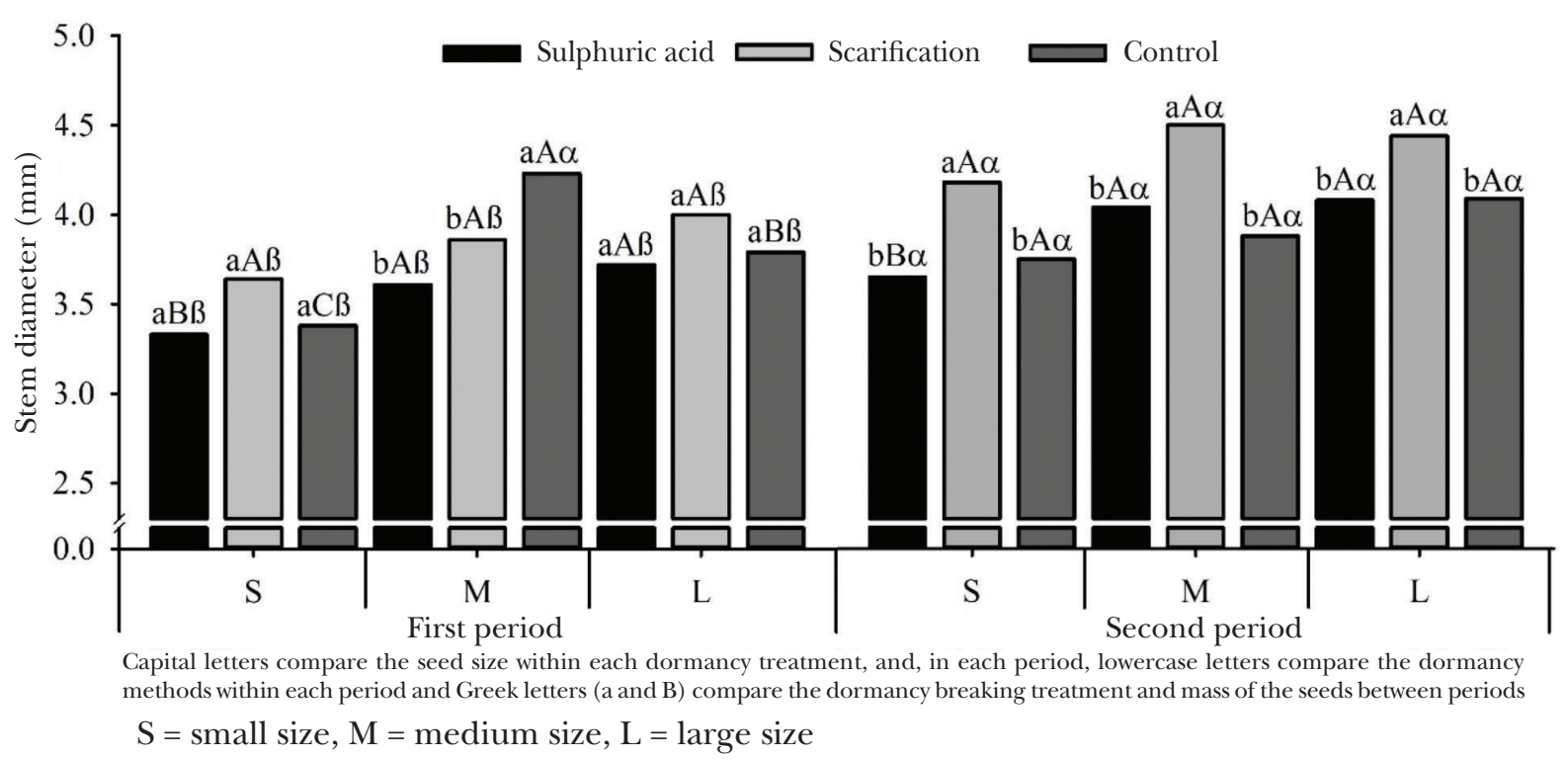

Figure 5 Effect of storage, seed mass and dormancy breaking methods on the seedling stem diameter of E. contortisiliquum

Seedling height had lower values in the second period independent of seed mass, with the exception of seedlings from untreated seeds. In treatments for breaking dormancy the highest seedling height was observed in small seeds in the first period. However, the same result was not observed for the second period. In the second period, treatments for breaking dormancy and seed mass did not influence plant height (Figure 7). Dresch et al. (2013) did not observe effect of fruit mass on the height of gabiroba plants (Campomanesia xanthocarpa). Similarly, Santos et al. (2013) found no effect of storage time on mulungu (Erythrina velutina) seeds. Alexandre et al. (2009) obtained the largest seedling lengths of E. contortisiliquum when the seeds were immersed in sulphuric acid for $10 \min (7.51 \mathrm{~cm})$ and scarified with sandpaper then soaked or not soaked in water (7.83 and $7.32 \mathrm{~cm}$ respectively). The reported mean seedling height values were 


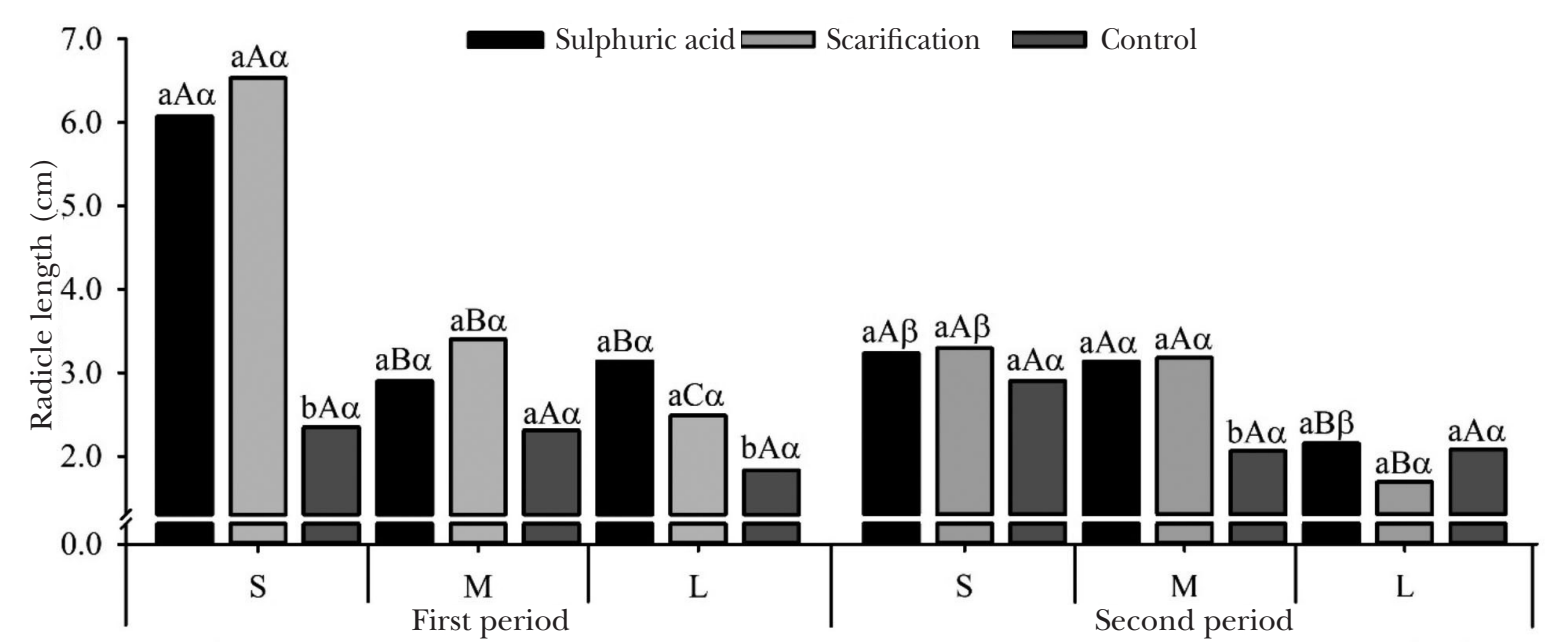

Capital letters compare the seed size within each dormancy treatment, and, in each period, lowercase letters compare the dormancy methods within each period and Greek letters ( $\mathrm{a}$ and $\mathrm{B}$ ) compare the dormancy breaking treatment and mass of the seeds between periods $\mathrm{S}=$ small size, $\mathrm{M}=$ medium size, $\mathrm{L}=$ large size

Figure 6 Effect of periods, seed mass and dormancy breaking methods on radicle length of the seedlings of $E$. contortisiliquum

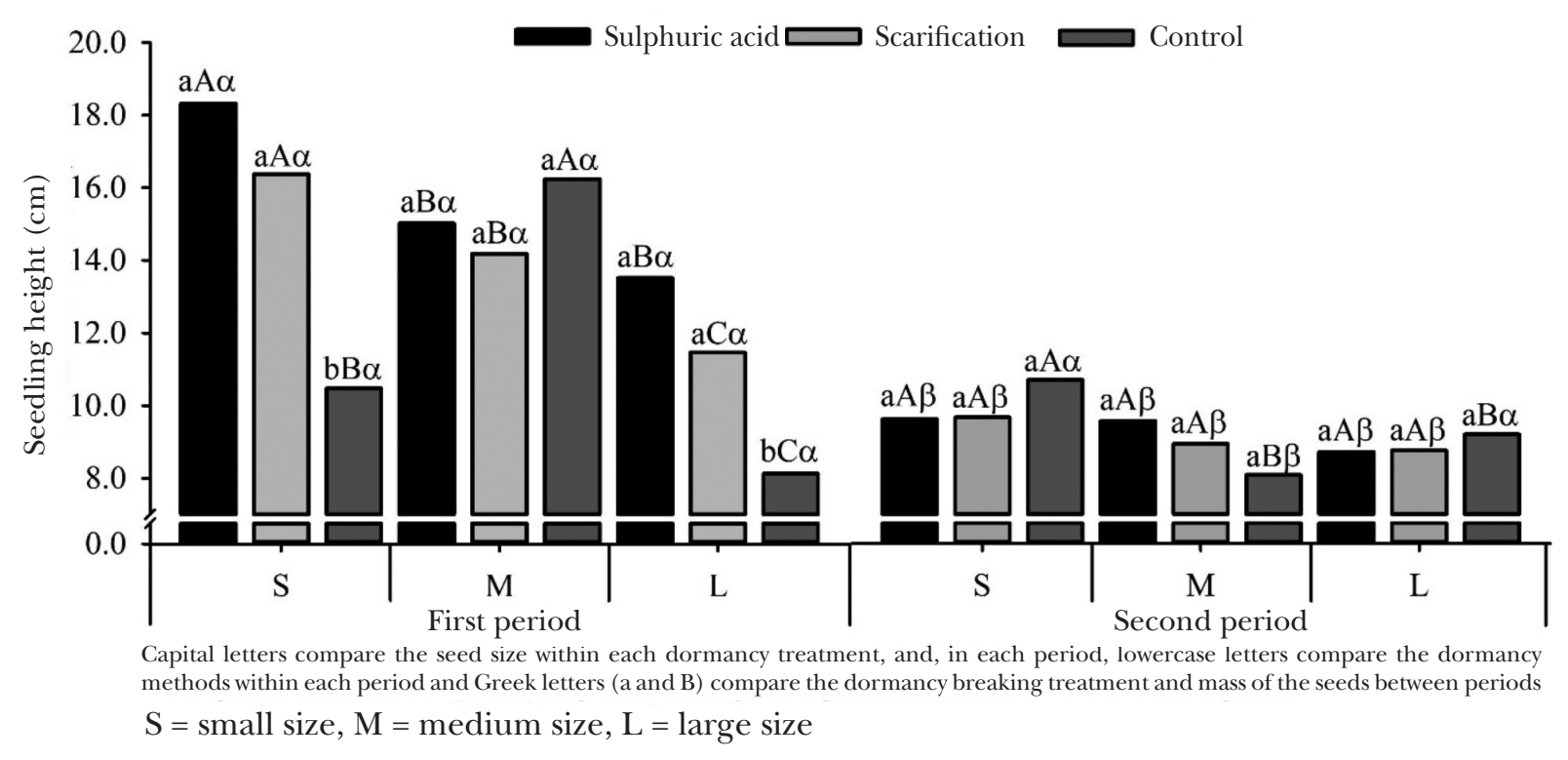

Figure 7 Effect of periods, seed mass and dormancy overcoming methods on aerial shoot growth of seedlings E. contortisiliquum

well below those of this study in the first period, but close to the average values obtained in the second period.

The average germination time did not show any differences from the effect of the dormancy breaking methods in the first period. Mechanical scarification in the second period showed the shortest average time in germination at approximately four days (Figure 8A). Among the total non-germinated seeds, around 95 (58.3\%) of the mechanically scarified, $82.6(45.8 \%)$ of those immersed in sulphuric acid and 3.8 (6.5\%) without scarification treatment in the second period, were found dead (Figure 8B). Similarly, when looking at seed mass, there was a lower percentage of ungerminated seeds for seeds that did not undergo dormancy breaking treatment (Figure 8C).

Referring to the remaining living seeds as a function of seed masses, those not subjected to dormancy breaking methods had the highest percentage of living seeds (Figure 8D). These 

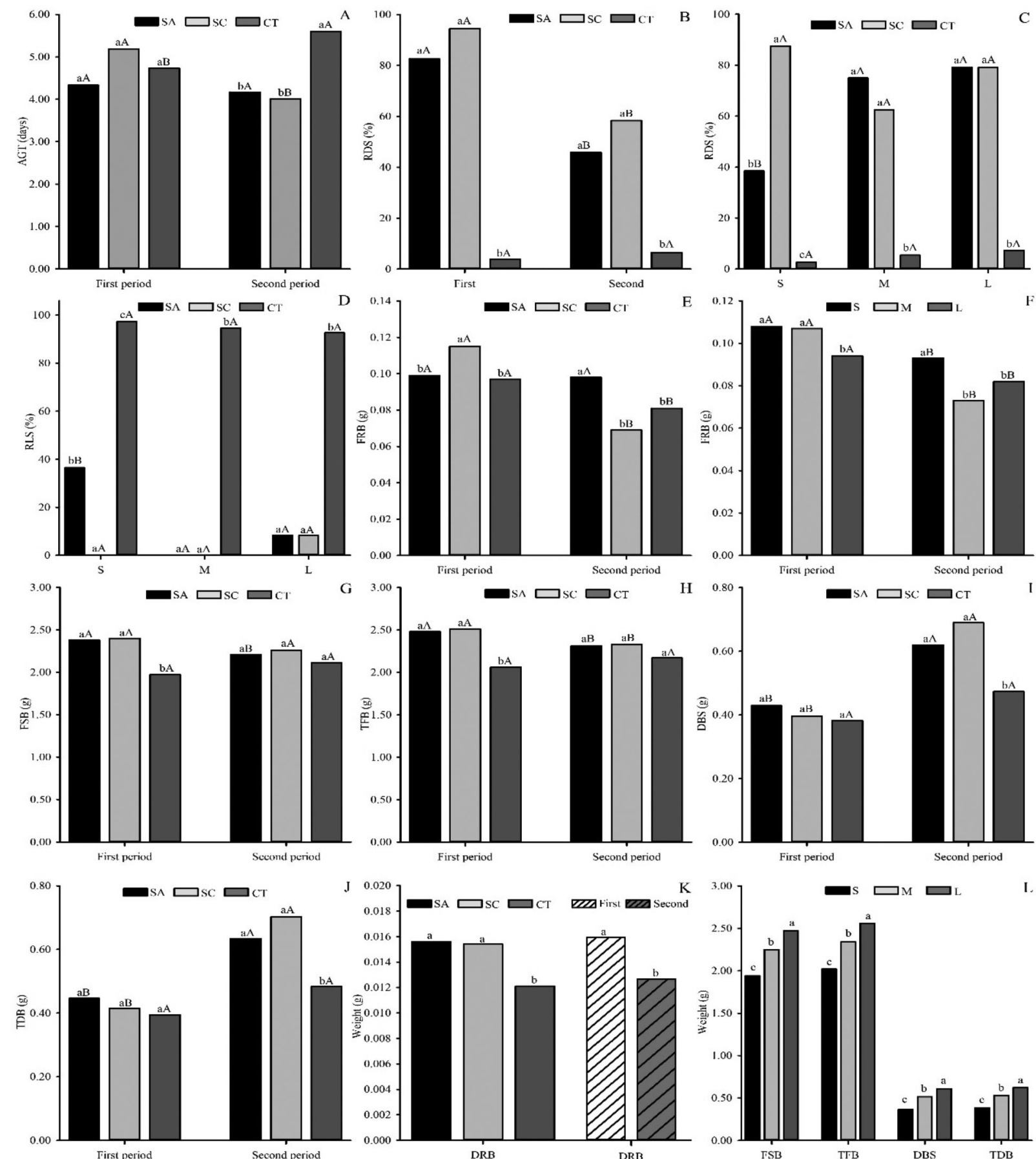

SA: sulphuric acid; SC: scarification; CT: control; AGT: average germination time; RDS: remaining dead seeds; RLS: remaining living seeds; FRB: fresh root biomass; FSB: fresh seeding biomass; TFB: total fresh biomass; DBS: dry biomass of seedlings; DRB: dry root biomass; TDB: total dry biomass

Lower case letters compare within the same treatment or variable and upper case letters compare the same treatments depending on the periods or seed mass; $\mathrm{S}=$ small size, $\mathrm{M}=$ medium size, $\mathrm{L}=$ large size

Figure 8 Effect of different treatments used on seeds and on seedling growth variables of E. contortisiliquum

results could be explained by the greater germination of seeds that were treated to overcome the impermeability of the integument (Figure 3).

The highest fresh root biomass in the first period was recorded in seedlings which underwent mechanical scarification, while in the second period the largest biomass was found in seedlings from seeds treated with sulphuric acid. Comparing the two periods, it was observed that in general the seedlings from the first period produced seedlings with higher biomass (Figure 
$8 \mathrm{E})$. This result was due to the fact that these seedlings had longer roots and more root mass (Figure 6).

For the analysis of seed sizes, it was observed that the large seeds regardless of the period, produced seedlings with smaller fresh root biomass. This was associated with the fact that in the second period, the seedlings produced lower root biomass and not affected by the seed mass (Figure 8F).

Fresh shoot biomass varied due to the dormancy breaking treatments in the first period, where the control group presented the lowest levels of fresh biomass accumulation. In the comparison between periods, it was found that only plants from seeds treated with sulphuric acid showed different results, with a higher biomass value in the first period (Figure 8G). As for total fresh biomass, seedlings treated with sulphuric acid and from mechanically scarified seeds had lower biomass value in the second period (Figure $8 \mathrm{H})$.

There was no difference in dry seedling biomass (Figure 8I) and total biomass (Figure 8J) with regards to dormancy breaking treatments in the first period. However, in the second period, seedlings from seeds which have undergone scarification (mechanical or chemical) showed greater biomass in the aerial part of the plant and in total biomass when compared with the control group (Figures 8I \& J). When comparing root dry biomass, higher values were found for the seedlings in the dormancy breaking treatments as compared with control. The dry mass of the roots was higher in the first period than in the second period (Figure 8K). Enterolobium contortisiliquum seeds of greater mass, produced seedlings with higher values of fresh shoot biomass, total fresh biomass and total dry biomass (Figure 8L).

According to Pereira et al. (2011) the influence of seed mass on germination and seedling vigour was to a certain extent species and region specific. Bezerra et al. (2002) verified that higher fresh biomass of the aerial part of Copaiba (Copaifera sp.) seedlings were originated from large seeds, validating the results of this study. Santos et al. (2013) studied the effect of methods for breaking dormancy and storage times for mulungu (Erythrina velutina) seeds, had found that there were no differences between root dry biomass and storage times.

Bruno et al. (2001) and Sampaio et al. (2001) who worked with Mimosa caesalpiniaefolia and
Bowdichia virgilioides, respectively, showed that seeds immersed in acid produced seedlings with greater dry mass. On the other hand, Santos et al. (2004) also used acid and manual scarification, found that there were no significant differences between treatments for dry matter production in the root system of Sterculia foetida. However, Oliveira et al. (2012) observed greater root dry mass in Parkia gigantocarpa (Fabaceae) seedlings, after the seeds were subjected to a longer sulphuric acid immersion. However, after considering the great difficulty in obtaining sulphuric acid and its hazardous corrosive nature, mechanical scarification was more favourable and emphasised.

\section{CONCLUSIONS}

The biometric characterisation of fruits and seeds in this study was able to provide support and information that facilitated the recognition of this species.

Mechanical scarification and immersion in sulphuric acid for $15 \mathrm{~min}$ proved to be efficient methods for breaking seed dormancy in E. contortisiliquum seeds. However, due to environmental and human health concerns, mechanical scarification was recommended. Enterolobium contortisiliquum seeds of medium $(0.887-1.090 \mathrm{~g})$ to large $(>1.090 \mathrm{~g})$ sizes were best suited for seedling production.

\section{ACKNOWLEDGEMENTS}

We thanked the Mato Grosso State Research Support Foundation (FAPEMAT) and the National Council for Scientific and Technological Development $(\mathrm{CNPq})$ for the provision of grants and to the Mato Grosso Federal Institute of Education, Science and Technology for their logistical and financial support.

\section{REFERENGES}

Alexandre RS, Gonçalves FG, Rocha AP et al. 2009. Tratamentos físicos e químicos na superação de dormência em sementes de Enterolobium contortisiliquum (Vell.) Morong. Revista Brasileira de Ciências Agrárias 4: 156-159.

Andrade LA, Bruno RLA, Oliveira LSB et al. 2010. Aspectos biométricos de frutos e sementes, grau de umidade e superação de dormência de jatobá. Acta Scientiarum. Agronomy 32: 293-299.

Araujo EC, Mendonça AVR, Barroso DG et al. 2004. Caracterização morfológica de frutos, sementes e 
plântulas de Sesbania virgata (Cav.) Pers. Journal of Seed Science 26: 105-110.

BARRETTO SSB \& FERREIRA RA. 2011. Aspectos morfológicos de frutos, sementes, plântulas e mudas de Leguminosae Mimosoideae: Anadenanthera colubrina (Vellozo) Brenan e Enterolobium contortisiliquum (Vellozo) Morong. Journal of Seed Science 33: 223-232.

Benedito Cp, Torres Sh, Ribeiro MCC et Al. 2008. Superação da dormência de sementes de catanduva (Piptadenia moniliformis Benth.). Revista Ciência Agronômica 39: 90-93.

Bezerra AME, Medeiros Filho S, Moreira MG et al. 2002. Germinação e desenvolvimento de plântulas de copaíba em função do tamanho e da imersão da semente em ácido sulfúrico. Revista Ciência Agronômica 33: 5-12.

Braga LF, Sousa MP, Gilberti S et AL. (2007) Caracterização morfométrica de sementes de castanha de sapucaia (Lecythis pisonis Cambess - Lecythidaceae). Revista Ciências Agro-Ambientais 5: 111-116.

Bruno RLA, Alves EU, Oliveira AP et al. 2001. Tratamentos pré-germinativos para superar a dormência de sementes de Mimosa caesalpiniaefolia Benth. Journal of Seed Science 23: 136-143.

Cardooso EA, Alves AU, Cavalcante ÍHL et al. 2012 Métodos para superação de dormência em sementes de leucena. Amazonian Journal of Agricultural and Environmental Sciences 55: 220-224.

Coelho MFB, Maia SSS, Oliveira AK et al. 2010. Superação da dormência tegumentar em sementes de Caesalpinia ferrea Mart ex Tul. Revista Brasileira de Ciências Agrárias 5: 74-79.

Costa PA, Lima ALS, Zanella F et al. 2010. Quebra de dormência em sementes de Adenanthera pavonina L. Pesquisa Agropecuária Tropical 40: 83-88.

Cruz ED \& Carvalho JEU. 2003. Biometria de frutos e germinação de sementes de Couratari stellata A. C. Smith (Lecythidaceae). Acta Amazonica 33: 381-388.

Czeder LP, Fernandes DC, Freitas JB et al. 2012. Baru almonds from different regions of the Brazilian Savanna: Implications on physical and nutritional characteristics. Agricultural Sciences 3: 745-754.

Dresch DM, Scalon SPQ, Masetto TE et al. 2013. Germinação e vigor de sementes de gabiroba em função do tamanho do fruto e semente. Pesquisa Agropecuária Tropical 43: 262-271.

EDWARDS TI. 1934. Relations of germinating soybeans to temperature and length of incubation time. Plant Physiology 9: 1-30.

Gama JSN, Alves EU, Bruno RLA et al. 2011. Superação de dormência em sementes de Centrosema plumieri Benth. Journal of Seed Science 33: 643-651.

Gonçalves LGV, Andrade FR, Marimon Junior BH et al. 2013. Biometria de frutos e sementes de mangaba (Hancornia speciosa Gomes) em vegetação natural na região leste de Mato Grosso, Brasil. Revista de Ciências Agrárias 36: 31-40.

Gusmão E, Vieira FA \& Fonseca Júnior ÉM. 2006. Biometria de frutos e endocarpos de murici (Byrsonima verbascifolia Rich. ex A. Juss.). Cerne 12: 84-91.

KHAN ML. 2004. Effects of seed mass on seedling success in Artocarpus heterophyllus L., a tropical tree species of north-east India. Acta Oecologica 25: 103-110.
Klein J, Zucareli V, Kestring D et al. 2007. Efeito do tamanho da semente na emergência e desenvolvimento inicial de mudas de pitangueira (Eugenia uniflora L.). Revista Brasileira de Biociências 5: 861-863.

Lessa Bft, Almeida JPN, Pinheiro Cl et al. 2014. Germinação e crescimento de plântulas de Enterolobium contortisiliquum (Vell.) Morong em função da localização da semente no fruto e regimes de temperatura. Bioscience Journal 30: 1474-1483.

Lozano Ec, Zapater Ma, Mamani C et al. 2016. Efecto de pretratamientos en semillas de Enterolobium contortisiliquum (Fabaceae) de la selva pedemontana Argentina. Boletin de la Sociedad Argentina de Botanica 51: 79-87.

Maguire JD. 1962. Speed of germination-aid in selection and evaluation for seedling emergence and vigor. Crop Science 2: 176-177.

MAPA - Ministério da Agricultura, Pecuária e Abastecimento. 2009. Regras para análise de sementes. MAPA, Brasília.

Melo MGG, Mendonça MS, NazÁrio P et al. 2011. Superação de dormência em sementes de três espécies de Parkia spp. Journal of Seed Science 33: 533-542.

MMA - Ministerio do Meio Ambiente. 2010. Florestas do Brasil em resumo - 2010: dados de 2005-2010. SFB. Brasília.

Moraes PLR \& Alves MC. 2002. Biometria de frutos e diásporos de Cryptocarya aschersoniana Mez e Cryptocarya moschata Nees (Lauraceae). Biota Neotropica 2: 1-11.

Oliveira AKM, Ribeiro JWF, Pereira KCL et al. 2012. Superação de dormência em sementes de Parkia gigantocarpa (Fabaceae - Mimosidae). Ciência Florestal 22: 533-540.

Oliveira AKM, Schleder ED \& Favero S. 2006. Caracterização morfológica, viabilidade e vigor de sementes de Tabebuia aurea (Silva Manso) Benth. \& Hook. f. ex. S. Moore. Revista Árvore 30: 25-32.

Pereira SR, Giraldelli GR, Laura VA et al. 2011. Tamanho de frutos e de sementes e sua influência na germinação de jatobá-do-cerrado (Hymenaea stigonocarpa var. stigonocarpa Mart. ex Hayne, Leguminosae- Caesalpinoideae). Journal of Seed Science 33: 141-148.

Sampaio LSV, Peixoto CP, Peixoto MDFDSP et al. 2001. Ácido sulfúrico na superação da dormência de sementes de sucupira-preta (Bowdixhia virgiloides H.B.K. - Fabaceae). Journal of Seed Science 23: 184-190.

SANTARÉm ER \& AQuila MEA. 1995 Influência de métodos de superação de dormência e do armazenamento na germinação de sementes de Senna macranthera (Colladon) Irwin \& Barneby (Leguminosae). Journal of Seed Science 17: 205-209.

Santos HM \& Santos GA. 2010. Superação de dormência em sementes de Enterolobium contortisiliquum (Vell.) Morong. Enciclopédia Biosfera 6: 1-11.

Santos LW, Coelho MFB, Maia SSS et al. 2013. Armazenamento e métodos para a superação da dormência de sementes de mulungu. Semina: Ciências Agrárias 34: 171-178.

Santos TO, Morais TGO \& Matos VP. 2004. Escarificação mecânica em sementes de chichá (Sterculia foetida L.). Revista Árvore 28: 1-6.

Santos Neto Al, Medeiros Filho S, Teófilo Em et al. 2009. Influência do peso da semente e promotores 
químicos na qualidade fisiológica de sementes de sambacaitá. Revista Caatinga 22: 187-192.

SAyre R, Bow J, Josse C ET AL. 2008. Terrestrial ecosystems of South America. Pp 131-152 in: Campbell JC, Bruce Jones K, Smith JH (eds) North America Land Cover Summit. American Association of Geographers, Washington.

Scalon SPQ, Mussury RM, Wathier F et al. 2005. Armazenamento, germinação de sementes e crescimento inicial de mudas de Enterolobium contortisiliquum (Vell.) Morong. Acta Scientiarum. Biological Sciences 27: 107-112.

Silva ACF, Silveira LP, Nunes IG et Al. 2012. Superação de dormência de Enterolobium contortisiliquum Mor. (Vell.) Morong. Scientia Plena 8: 1-6.

Silva RSM, Chaves LJ \& Naves RV. 2001. Caracterização de frutos e árvores de cagaita (Eugenia dysenterica DC.) no sudeste do estado de Goiás, Brasil. Revista Brasileira de Fruticultura 23: 330-334.

Socolowski F, Vieira DCM \& TAKaki M. 2013. Massa das sementes de Tecoma stans L. Juss. ex Kunth (Bignoniaceae): efeitos na emergência e desenvolvimento de suas plântulas no sol e na sombra. Biota Neotropica 11: 171-178.
Upadhaya K, Pandey HN \& Law PS. 2007. The effect of seed mass on germination, seedling survival and growth in Prunus jenkinsii Hook.f. \& Thoms. Turkish Journal of Botany 31: 31-36.

White JW \& González A. 1990. Characterization of the negative association between seed yield and seed size among genotypes of common bean. Field Crops Research 23: 159-175.

Wielewick AP, Leonhardt C, Schlindwein G et Al. 2006. Proposta de padrões de germinação e teor de água para sementes de algumas espécies florestais presentes na região sul do Brasil. Journal of Seed Science 28: 191-197.

Zonta JB, Araujo EF, Araujo RF et al. 2011. Efeito da massa específica e do tamanho/espessura na qualidade fisiológica de sementes de pinhão-manso. Revista Brasileira de Oleaginosas e Fibrosas 15: 17-26.

Zuffo AM, Andrade FR \& Zuffo Júnior JM. 2014. Caracterização biométrica de frutos e sementes de baru (Dipteryx alata Vog.) na região leste de Mato Grosso, Brasil. Revista de Ciências Agrárias 37: 463-471. 